Research Article

\title{
PERFORMANCE OF DIFFERENT CULTIVARS OF MUNGBEAN IN COASTAL REGION OF BANGLADESH
}

\author{
K.N. Islam ${ }^{1}$, M.M.H. Khan ${ }^{2}$, M.M. Islam ${ }^{3}$, M.M. Uddin ${ }^{4}$ and M.A. Latif ${ }^{5}$ \\ ${ }^{1}$ OFRD, Bangladesh Agricultural Research Institute, Patuakhali, Bangladesh \\ ${ }^{2}$ Dept. of Entomology, Patuakhali Science and Technology University, Bangladesh \\ ${ }^{3}$ SCWMC, Soil Resource Development Institute (SRDI), Bandarban, Bangladesh \\ ${ }^{4}$ Dept. of Entomology, Bangladesh Agricultural University, Mymensingh, Bangladesh \\ ${ }^{5}$ Dept. of Entomology, Sher-e-Bangla Agricultural University, Dhaka, Bangladesh
}

\begin{abstract}
The study was conducted at farmers' field of Itbaria, Patuakhali sadarupazila under Patuakhali district during January to April 2016under the agro ecological zone AEZ-13 (Ganges Tidal Flood plain). This site was located in between $22^{\circ} 14^{\prime}$ and $22^{\circ} 29^{\prime}$ North latitudes and in between $90^{\circ} 12^{\prime}$ and $90^{\circ} 28^{\prime}$ East longitudes of Bangladesh. Fifteenmungbean varieties viz., BARI Mung-1, BARI Mung-2, BARI Mung-3, BARI Mung-4, BARI Mung-5, BARI Mung-6, BINA Moog-4, BINA Moog-5, BINA Moog6. BINA Moog-7, BINA Moog-8, BU Mug-1, BU Mug-2, BU Mug-4 and Patuakhali local Mung were tested to select best suitable variety for costal region. The experiment was laid out in randomized complete block design (RCBD) with threereplications. Significant variation was observed among the different mungbeanvarities in respect of majority of the observed parameters.BU Mug-1 showed the tallest plant height while the tallest pod length was observed in BARI Mung-5. The highest number of branches per plant was found in BINA Moog-4 whereas the highest number of leaves per plant found for BARI Mung-6. The highest seed yield and yield attributes like number of pods per plant, number of seeds per pod and 1000 seed weight was recorded in BARI Mung- 6 followed by BINA Moog-8 while Patuakhali local Mung produced the lowest yield and attributes. Most of the yield contributing factors of BARI Mung- 6 wasfavorable for better yield in coastal region of Bangladesh. Hence the mungbean production can be increased by introducingBARI Mung- 6 in costal region.
\end{abstract}

Keywords: Factor, Mungbean, Varieties, Yield

\footnotetext{
*Corresponding author: kbd_nazrul@yahoo.com
} 


\section{INTRODUCTION}

Mungbean (Vigna radiata L. Wilczek) alternatively known as the moog bean or green gram, is a plantspeciesin the legume family. Mungbean is one of the most important pulse crops of Bangladesh. It is considered as the best of all pulses from the nutritional point of view. It has a good digestibility and flavor. It is an excellent source of protein $(24.5 \%)$ with high quality of lysine $\left(460 \mathrm{mg} \mathrm{g}^{-1} \mathrm{~N}\right)$ and tryptophan $\left(60 \mathrm{mg} \mathrm{g}^{-1} \mathrm{~N}\right)$. It also contains remarkable quantity of ascorbic acid and riboflavin $\left(0.21 \mathrm{mg} 100 \mathrm{~g}^{-1}\right)$ (Azadi et al., 2013). Besides providing protein in the diet, mungbean has the remarkable quality of helping the symbiotic root rhizobia to fix atmospheric nitrogen and hence to enrich soil fertility (Anjum et al.,2006) which not only enables it to meet its own nitrogen requirement but also benefits the succeeding crops (Ali, 1992). The rice based cropping pattern has been found as an important cropping system in our country, as such condition short duration crop mungbean can easily be fit as a cash crop between major cropping seasons.

It is a major pulse crop in Asia. Countries like Bangladesh, Bhutan, China, India, Myanmar, Nepal, Pakistan, Sri Lanka and Thailand collaborated with AVRDC (Asian Vegetable Research and Development Centre) using an integrated, interdisciplinary approach to research and develop improved mungbean varieties and technologies. The agro-ecological condition of Bangladesh is favorable for growing this crop. The optimum temperature ranges from $20^{\circ}-35^{\circ} \mathrm{C}$ depending upon season (BARC, 2013). Mungbean is also drought tolerant and can grow with a minimum supply of nutrients.It is grown in area of 1.82 lakh hectares with total production of 1.98 lakh metric tons in Bangladesh (Krishi Diary, 2016).In spite of the best efforts for improving the mungbean varieties, the productivity of this crop is lowi.e. only around $500 \mathrm{~kg} \mathrm{ha}{ }^{-1}$. The low productivity can be attributed to lack of suitable genotypes for different cropping situations (Dikshit et al., 2009). It is grown in three seasons in a year in Bangladesh and more than $70 \%$ mungbean area is concentrated in the three southern districts viz. Patuakhali, Barisal, and Noakhali within AEZ 13 and 18 and Patuakhali alone occupies about 30\% area (Mondolet al., 2013). Mungbean is usually sown in this region at the end of January to mid February. Most of the soils in this region are cracking clay type which becomes compact and hard on drying (Choudhury et al., 2000).

The reasons for low yield of mungbean are varietal and management factors. Due to the lack of land, the scope of its wide-ranging cultivation is very inadequate. Farmers commonly grow mungbean by one ploughing and scarcely use any fertilizer and irrigation due to its lower yield and also to their poor socio-economic circumstance and lack of proper information. Thus, the yield becomes low. The shortfall situation of mungbean production in our country can be conquer either by bringing more area under mungbean cultivation or by increasing the yield through improvement of production technology, such as optimizing the high yielding variety and improved technology. Bangladesh agroclimatical condition differed in differentareas and 
mungbeanvarities performed differently. This study done on mungbean varieties would help farmers to select and cultivate best suitable variety under coastal region of Bangladesh.

\section{MATERIALS AND METHODS}

\section{Climate and Soil}

The study was conducted at farmers' field of Itbaria, Patuakhali Sadar Upazilla in the Patuakhali district, the coastal region under the agro ecological zone AEZ-13 (Ganges Tidal Flood plain) which is located between $22^{\circ} 14^{\prime}$ and $22^{\circ} 29^{\prime}$ North latitudes of Bangladesh. The experiment was setup during January to April 2016 in the Rabi season (October to March). Rabi season (October to March) is characterized by comparatively low temperature and plenty of sunshine from November to February. Particularly in the areas of southern coastal region, mungbean crop could be grown in late Rabi (winter period) from mid January to mid February. The winter period is short in this area due to close proximity to the Bay of Bengal. The experimental site is also adjacent to the Bay of Bengal. The area lies at 0.9 to 2.1 metre above mean sea level (Iftekhar and Islam, 2004). The soil of the experimental area was non-calcareous and slightly saline $(2.6 \mathrm{dS} / \mathrm{m})$, silty clay in texture and neutral in reaction $(\mathrm{pH} 6.7)$. Fertility status of soil in general is poor with a low level of organic matter (1.56). Total nitrogen $(0.105 \%)$ level in soil is low, phosphorous $(4.69 \%)$ very low and potassium $(0.40 \%)$ high. Land type is medium high land and the major area $(74.6 \%)$ is medium high land (SRDI, 2005).

\section{Experimental layout and Plant materials}

The experiment was laid out in a randomized complete block design (RCBD) with 3 replications. Each replication represented a block which was divided into fifteen-unit plots. The unit plots $(4 \mathrm{~m} \times 2.5 \mathrm{~m})$ were made ready as per design with a distance of $0.5 \mathrm{~m}$ between the plots and $1 \mathrm{~m}$ between the replications. Fifteen (15) Mungbean varieties were randomly allotted to the plot within a block. The seeds of mungbeanvarieties viz., BARI Mung-1, BARI Mung-2, BARI Mung-3, BARI Mung4, BARI Mung-5, BARI Mung-6 were collected from Bangladesh Agricultural Research Institute (BARI), Gazipur, BINA Moog-4, BINA Moog-5, BINA Moog-6, BINA Moog-7, BINA Moog-8 from Bangladesh Institute of Nuclear Agriculture (BINA), Mymensingh, BU Mug-1, BU Mug-2, BU Mug-4 from Bangabandhu Sheikh Mujibur Rahman Agricultural University (BSMRAU), Gazipuand Patuakhali local Mung variety from farmers' of Patuakhali. BARI, BINA and BSMRAU have developed mungbean varieties, but these varieties earlier not tested properly in coastal region. The varieties and their important characteristics are presented below:

\section{BARI Mung-1}

This variety was introduced from India (M-7706). Plant height: $45-50 \mathrm{~cm}$. Tolerant to CLS. Photo insensitive. Protein: $25.50 \%$, CHO: $47.30 \%$. Head dhal yield: $72.0 \%$. 
Cooking time: $14 \mathrm{~min}$. Seed color is green. 1000 seed weight: $25.40 \mathrm{~g}$. Seed yield: 0.9-1.0 $\mathrm{t} \mathrm{ha}^{-1}$. Duration: 65-70 days.

\section{BARI Mung-2}

This variety was introduced from Philippine (M-7715). Plant height: $45-52 \mathrm{~cm}$. Tolerant to YMV and CLS. Photo insensitive. Protein: $22.56 \%$, CHO: $46.15 \%$. Head dhal yield: $76.1 \%$. Cooking time: $15 \mathrm{~min}$. Seed color is green. 1000 seed weight: 25.33g. Seed yield: 1.1-1.35 $\mathrm{t} \mathrm{ha}^{-1}$. Duration: 65-70 days.

\section{BARI Mung-3}

This variety was developed from crossing between Sona mung and BARI Mung-2. Plant height: $50-55 \mathrm{~cm}$. Tolerant to YMV and CLS. Photo insensitive. Protein: 20.81\%, CHO: $49.53 \%$. Head dhal yield: $67.5 \%$. Cooking time: 15 min. Seed color is brownish green. 1000 seed weight: $29.4 \mathrm{~g}$. Seed yield: $1.0-1.3 \mathrm{t} \mathrm{ha}^{-1}$. Duration: $60-65$ days.

\section{BARI Mung-4}

This variety was developed from local cross (BMX 841121). Plant height: $52-57 \mathrm{~cm}$. Resistant to YMV and CLS. Photo insensitive. Protein: 23.1\%, CHO: 51.32\%. Head dhal Yield: $68 \%$. Cooking time: 17 min. Seed color is green. 1000 seed weight: 31.9g. Seed yield: 1.2-1.4 tha ${ }^{-1}$. Duration: 60-65 days.

\section{BARI Mung-5}

This variety was introduced from AVRDC (NM- 92). Plant height: 41-46 cm. Resistant to YMV and CLS. Photo insensitive. Protein: 20.93\%, CHO: 49.46\%. Head dhal Yield: $68 \%$. Cooking time: $18 \mathrm{~min}$. Quite Synchrony in maturity. Seed color is deep green. 1000 seed weight: $41.9 \mathrm{~g}$. Seed yield: $1.40-1.45 \mathrm{t} \mathrm{ha}^{-1}$. Duration: $58-60$ days.

\section{BARI Mung-6}

This variety was introduced from AVRDC (NM- 94). Medium plant stature. Plant height: $40-45 \mathrm{~cm}$. Resistant to YMV and CLS. Photo insensitive. Bold seed size with green seed coat. Protein: 21.2\%; CHO: 46.8\%. Head dhal Yield: $67.2 \%$. Cooking time: $18 \mathrm{~min}$. Synchrony in maturity and late potentiality. Recommended for cultivation in Jessore, Khulna, Faridpur, Pabna, Rajshahi and Dinajpur. Seed color is deep green. 1000 seed weight: $40.0 \mathrm{~g}$. Seed yield: $1.5-1.6 \mathrm{t} \mathrm{ha}^{-1}$. Duration: 55-60 days.

\section{BINA Moog-4}

A high yielding winter mungbean variety, released in 1997. Plant height: $28-32 \mathrm{~cm}$. It matures between 75-80 days. Seed size is bigger than Bina moog 1. All the pods mature at a time. Protein: $23.0 \%$. Plants are short and tolerant to CLS and YMV. Pods have prominent ridges. Seed color is dull green. 1000 seed weight: $37.50 \mathrm{~g}$. Maximum seed yield potential is $1.2 \mathrm{t} \mathrm{ha}^{-1}$ (av. $1.1 \mathrm{tha}^{-1}$ ). 


\section{BINA Moog-5}

A late winter-cum-summer mungbean variety, released in 1998. Plant height: 40-45 $\mathrm{cm}$. It matures between 70-80 days. Seed is green shiny and bigger than BINA Moog-1. Almost all the pods mature at a time. Protein: $23.0 \%$. Seed color is bright green. 1000 seed weight: 35-40 g. Plants are short and tolerant to CLS and YMV. Maximum seed yield potential is $2.0 \mathrm{tha}^{-1}$ (av. $1.5 \mathrm{tha}^{-1}$ ).

\section{BINA Moog-6}

This is an early mature summer mungbean variety, released in 2005. Plant height: 35$40 \mathrm{~cm}$. It matures between 64-68 days. Almost all the pods mature at a time. Protein: $23.0 \%$. Seed color is bright green. 1000 seed weight: $35-40 \mathrm{~g}$. The variety is tolerant to CLS and YMV. Average yield is up to $1.5 \mathrm{t} \mathrm{ha}^{-1}$.

\section{BINA Moog-7}

This is a high yielding summer mungbean variety, released in 2005. Plant height: 40$45 \mathrm{~cm}$. It matures between 70-74 days. Almost all the pods mature at a time. Protein: 23.0\%. Seed color is green. 1000 seed weight: $35-40 \mathrm{~g}$. The variety is tolerant to CLS and YMV. Average yield is up to $1.8 \mathrm{tha}^{-1}$.

\section{BINA Moog-8}

This is a summer mungbean variety, released in 2010. It is obtained from seeds of MB-149 which were irradiated with 400 Gy dose of gamma ray. Maturity period ranges from 64-67 days. Maximum grain yield is about $2.0 \mathrm{t} \mathrm{ha}^{-1}$ (av. $\left.1.8 \mathrm{t} \mathrm{ha}^{-1}\right)$. Seed is medium size with green shiny color. Seed contains higher protein (23\%). Plants are short and tolerant to YMV. This variety is suitable for cultivation in pulse growing areas of Bangladesh.

\section{BU Mug-1}

This variety was developed from AVRDC- VC 6372 (45-8-1). Plants are short. Almost all the pods mature at a time. Resistant to YMV and CLS. Leaf and seed color is deep green. Seed yield: 1.40-1.60 $\mathrm{t} \mathrm{ha}^{-1}$. Duration: 55-60 days.

\section{BU Mug-2}

This variety was developed from AVRDC- VC 6370 (30-65). Plants are short. Almost all the pods mature at a time. Resistant to YMV and CLS. Leaf and seed color is deep green. Seed yield: 1.50-1.70 $\mathrm{t} \mathrm{ha}^{-1}$. Duration: 55-60 days.

\section{BU Mug-4:}

This variety was developed from AVRDC- GK 7. Plants are short. Tolerant to high moisture and rainfall in soil. Almost all the pods mature at a time. Resistant to YMV and CLS. Leaf and seed color is deep green. High moisture and rainfall. Seed yield: 1.80-2.00 $\mathrm{t} \mathrm{ha}^{-1}$. Duration: 55-60 days. 


\section{Land preparation and Fertilizer application}

The land was prepared at 'joe' condition by deep ploughing and cross-ploughing 4 times by power tiller followed by laddering until the desired tilth. All the weeds, residues and stubbles of the previous crops were removed from the field and the large clods were broken into smaller pieces to obtain a desirable tilth of soil for sowing of mungbean seeds. The fertilizers were applied as per fertilizers recommendation guide (BARI, 2011). Urea, TSP and MoP were applied in the field uniformly @ 50-85-35 $\mathrm{kg} / \mathrm{ha}^{-1}$, respectively during the final land preparation. The fertilizers were then mixed properly with the soil by spading and individual unit experimental plots were leveled.

\section{Seed sowing and Intercultural operations}

The mungbean seeds were sown on the $29^{\text {th }}$ January, 2016 at the rate of $30 \mathrm{~kg} / \mathrm{ha}$ (BARI, 2011) with making rows maintaining spacing $(30 \mathrm{~cm} \times 10 \mathrm{~cm})$ for mungbean cultivation. Seed sowing was done at a depth of 6-7 $\mathrm{cm}$ and the seeds were covered by loose soil with the help of hand. All intercultural operations were done as and when necessary to ensure normal growth and development of crops.

\section{Yield and yield attributing data collection of different mungbean varieties}

Five plants were selected at random from each plot to measure plant height $(\mathrm{cm})$, number of branches plant ${ }^{-1}$, number of leaves plant ${ }^{-1}$,number of pods plant ${ }^{-1}$, pod length $(\mathrm{cm})$, number of seeds pod $^{-1}$ (5 pods), 1000 seed weight $(\mathrm{g})$. Plant height was measured from the base of plant upto the top of the main shoot at reproductive stage and the mean plant height was expressed in centimeter $(\mathrm{cm})$. Number of branches plant $^{-1}$ and number of leaves plant ${ }^{-1}$ were counted from the inner rows of each plot at reproductive stage and were averaged. Number of pods plant ${ }^{-1}$ was counted from each plot at the ripening stage and average number of pods per plant was calculated. Pod length was measured by a meter scale from randomly selected 5 pods after harvesting. Mean value of them was calculated plot wise and the mean pod length was expressed in centimeter $(\mathrm{cm})$.Number of seeds per pod was recorded after harvesting of the crop from the randomly selected 5 pods from pre-selected 5 plants and was calculated from their mean values. 1000 grains were collected from randomly selected 5 plants of each plot and were weighed in gram by digital electric balance. Mature pods manually harvested by hand in Bangladesh when about $80 \%$ of the pods became blackish in colour. Grains obtained from $1 \mathrm{~m}^{2}(1 \mathrm{~m} \times 1 \mathrm{~m})$ area from the selected portion of the center of each unit plot that was harvested from the plots. The harvested pods of $1 \mathrm{~m}^{2}$ area from each unit plot were kept separately. The pods were properly dried in the sun, then beaten with a stick and threshed. After threshing, grains were recorded from $1 \mathrm{~m}^{2}$ area per plot wise and the yields were expressed in $\mathrm{kg} \mathrm{ha}^{-1}$.

\section{Statistical analysis}

The collected data were statistically analyzed through the analysis of variance using Web Agri Stat Package (WASP 1.0). Means were separated by critical difference (CD) values at $5 \%$ level of significance. 


\section{RESULTS AND DISCUSSIONS}

\section{Plant height (cm)}

Significant variation was found in case of plant height among the different varieties (Fig. 1). Plant height ranged from 31.73 to $43.80 \mathrm{~cm}$. The tallest plant was recorded in BU Mug-1 $(43.80 \mathrm{~cm})$ followed by BU Mug-4 $(41.40 \mathrm{~cm})$, BARI Mung-5 (41.26 $\mathrm{cm})$ and Patuakhali local Mung $(41.13 \mathrm{~cm})$. The shortest plant was recorded in BINA Moog-4 $(31.73 \mathrm{~cm})$ which was followed by BARI Mung-2 $(34.80 \mathrm{~cm})$ and BINA Moog-5 $(34.93 \mathrm{~cm})$. This dissimilarity in plant tallness might be attributed to the inherent factors. Similar findings of plant tallness were obtained by Farghali and Hussein (1995).

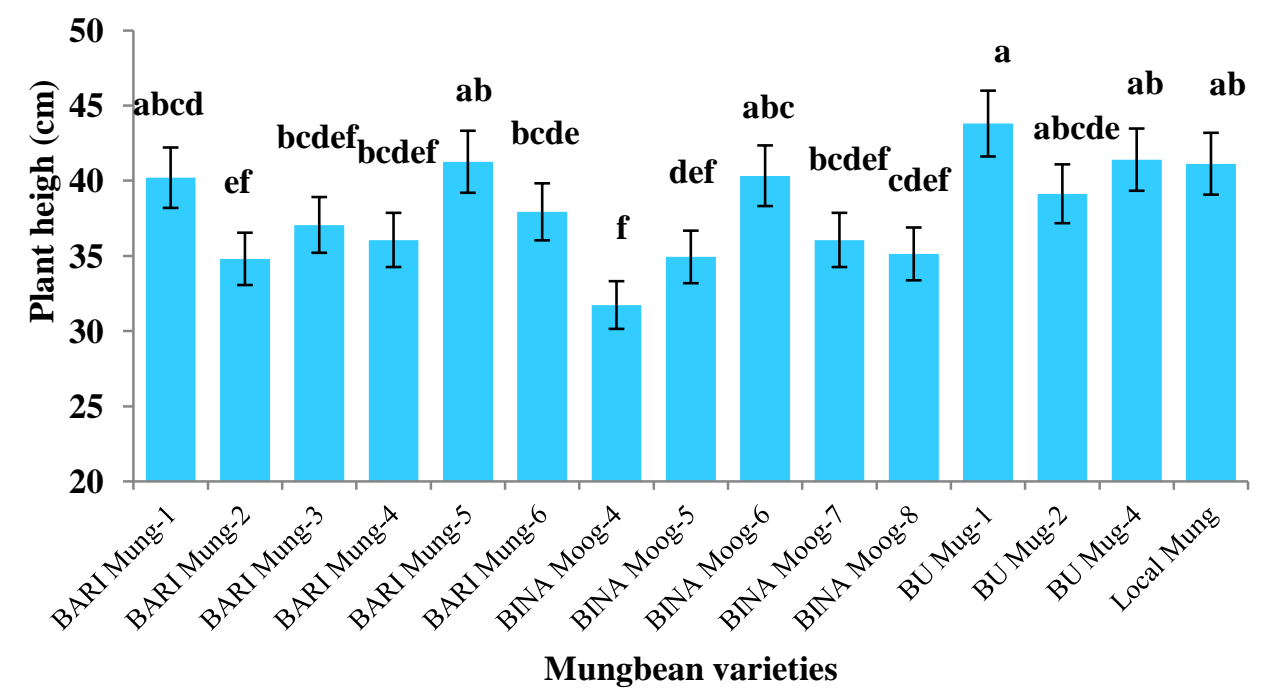

Figure 1. Effect of different varieties on the plant height of mungbean

\section{Number of branches per plant}

Number of branches per plant was significantly influenced by the different varieties (Fig. 2). The highest number of branches per plant (3.00) was observed in BINA Moog-4 followed by BARI Mung-2 (2.00) which was statistically similar to that of BARI Mung-3 (2.00), BARI Mung-6 (2.00), BINA Moog-5 (2.00) and BINA Moog7 (2.00). The lowest number of branches per plant (0.66) was obtained from BARI Mung-4 which was statistically identical to BU Mug-2 (0.66) which was statistically similar to BARI Mung-5 (1.00), BINA Moog-6 (1.00) and BINA Mung-8 (1.00). The other varieties showed intermediate type results. It might be due to their genetic capacity. The similar findings were also supported by Mishra (2003). 


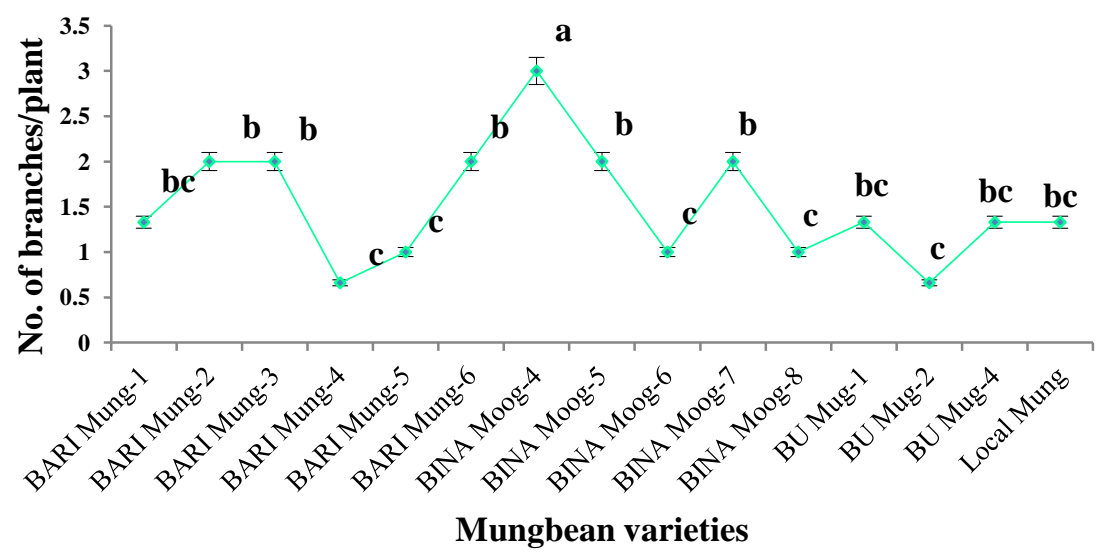

Figure 2. Effect of different varieties on the number of branches of mungbean

\section{Number of leaves per plant}

The number of leaves per plant counted was significantly influenced by different varieties (Fig. 3). The highest number of leaves per plant (10.00) was observed in BARI Mung-6 which was statistically identical to BINA Moog-4 (10.00) and BINA Moog-7 (10.00) which was significantly higher than all other varieties. The lowest number of leaves per plant (5.00) was obtained from BARI Mung-4 which was followed by BARI Mung-5 (5.66), BINA Moog-8 (6.00) and BU Mug-2 (6.00). The other varieties showed intermediate number of leaves in respect to the highest and the lowest values. It might be probably due to their inherent characters of varieties. Similar results reported by Hussain et al. (2011).

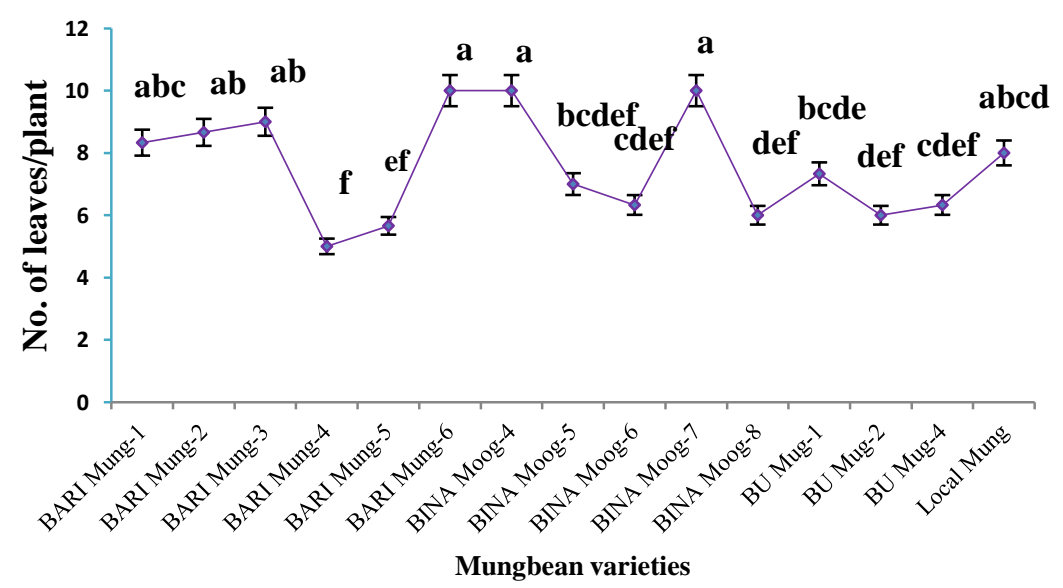

Figure 3. Effect of different varieties on the number of leaves of mungbean 


\section{Number of pods per plant}

The result of analysis of variance (Table 1) showed that the mungbean varieties differed significantly from each other in number of pods per plant. The variety BARI Mung-6 (18.33) produced the highest number of pods per plant followed by BARI Mung-2 (16.27) which was statistically similar to BINA Moog-8 (15.80). The lowest number of pods per plant was recorded in the Patuakhali local Mung (8.70) which was statistically similar to BINA Moog-7 (9.00), BARI Mung-1 (9.00) and BINA Moog-6 (9.10). Effective pods per plant were different with varieties due to genotypic variations also observed by Mondal et al. (2004) in mungbean.

Table 1. Yield and yield contributing factors of different mungbean varieties

\begin{tabular}{l|c|c|c|c}
\hline \multicolumn{5}{c}{ Yield and yield contributing factors } \\
\hline VArieties & $\begin{array}{c}\text { No. of pods } \\
\text { per plant }\end{array}$ & $\begin{array}{c}\text { No. of seeds } \\
\text { per pod }\end{array}$ & $\begin{array}{c}1000 \mathrm{seed} \\
\text { weight }(\mathrm{g})\end{array}$ & $\begin{array}{c}\text { Yield } \\
\left(\mathrm{kg} \mathrm{ha}^{-1}\right)\end{array}$ \\
\hline BARI Mung-2 & $9.00 \mathrm{~g}$ & 11.33 & $35.66 \mathrm{~g}$ & $602.67 \mathrm{~g}$ \\
BARI Mung-3 & $16.27 \mathrm{~b}$ & 11.66 & $37.66 \mathrm{f}$ & $675.33 \mathrm{ef}$ \\
BARI Mung-4 & $12.93 \mathrm{~cd}$ & 10.66 & $33.33 \mathrm{hi}$ & $713.00 \mathrm{def}$ \\
BARI Mung-5 & $10.33 \mathrm{efg}$ & 11.33 & $33.66 \mathrm{~h}$ & $808.67 \mathrm{c}$ \\
BARI Mung-6 & $11.40 \mathrm{def}$ & 11.33 & $45.66 \mathrm{~b}$ & $940.33 \mathrm{~b}$ \\
BINA Moog-4 & $9.80 \mathrm{fg}$ & $11.33 \mathrm{a}$ & $48.33 \mathrm{a}$ & $1065.33 \mathrm{a}$ \\
BINA Moog-5 & $13.53 \mathrm{c}$ & 11.00 & $36.00 \mathrm{~g}$ & $650.00 \mathrm{fg}$ \\
BINA Moog-6 & $9.10 \mathrm{~g}$ & 10.66 & $34.00 \mathrm{c}$ & $778.67 \mathrm{~cd}$ \\
BINA Moog-7 & $9.00 \mathrm{~g}$ & 11.00 & $32.33 \mathrm{i}$ & $746.33 \mathrm{~cd}$ \\
BINA Moog-8 & $15.80 \mathrm{~b}$ & 11.66 & $37.66 \mathrm{f}$ & $1004.33 \mathrm{ab}$ \\
BU Mug-1 & $11.33 \mathrm{def}$ & 11.66 & $38.00 \mathrm{f}$ & $586.67 \mathrm{~g}$ \\
BU Mug-2 & $11.63 \mathrm{de}$ & 10.66 & $41.00 \mathrm{~d}$ & $603.33 \mathrm{~g}$ \\
BU Mug-4 & $12.63 \mathrm{~cd}$ & 10.66 & $42.00 \mathrm{~d}$ & $725.67 \mathrm{de}$ \\
Patuakhali & $8.70 \mathrm{~g}$ & 10.66 & $31.00 \mathrm{j}$ & $490.00 \mathrm{~h}$ \\
local Mung & 8.15 & 6.46 & 2.04 & 5.36 \\
\hline CV (\%) & 1.63 & $\mathrm{NS}$ & 1.31 & 65.71 \\
CD (0.05) & & & & \\
\hline
\end{tabular}

In a column means having dissimilar letter(s) differ significantly as per 0.05 level of probability. CD - Critical Difference 


\section{Pod length (cm)}

Pod length which is one of the most important yield contributing factors of mungbean differed significantly among the different varieties (Fig. 4). The tallest pod length $(9.45 \mathrm{~cm})$ was observed in BARI Mung-5 which was statistically identical to BARI Mung-6 $(9.44 \mathrm{~cm})$ followed by BINA Moog-8 (8.83) and BU Mug-2 (8.78). The shortest pod length $(7.10 \mathrm{~cm})$ was obtained in BINA Moog-7 which followed by Patuakhali local Mung $(7.22 \mathrm{~cm})$ and BARI Mung-3 $(7.30 \mathrm{~cm})$. These results have the agreement with the results of Parvez et al. (2013) who reported that pod length differed from varieties to varieties. The probable reason of this difference could be the genetic make-up of the varieties.

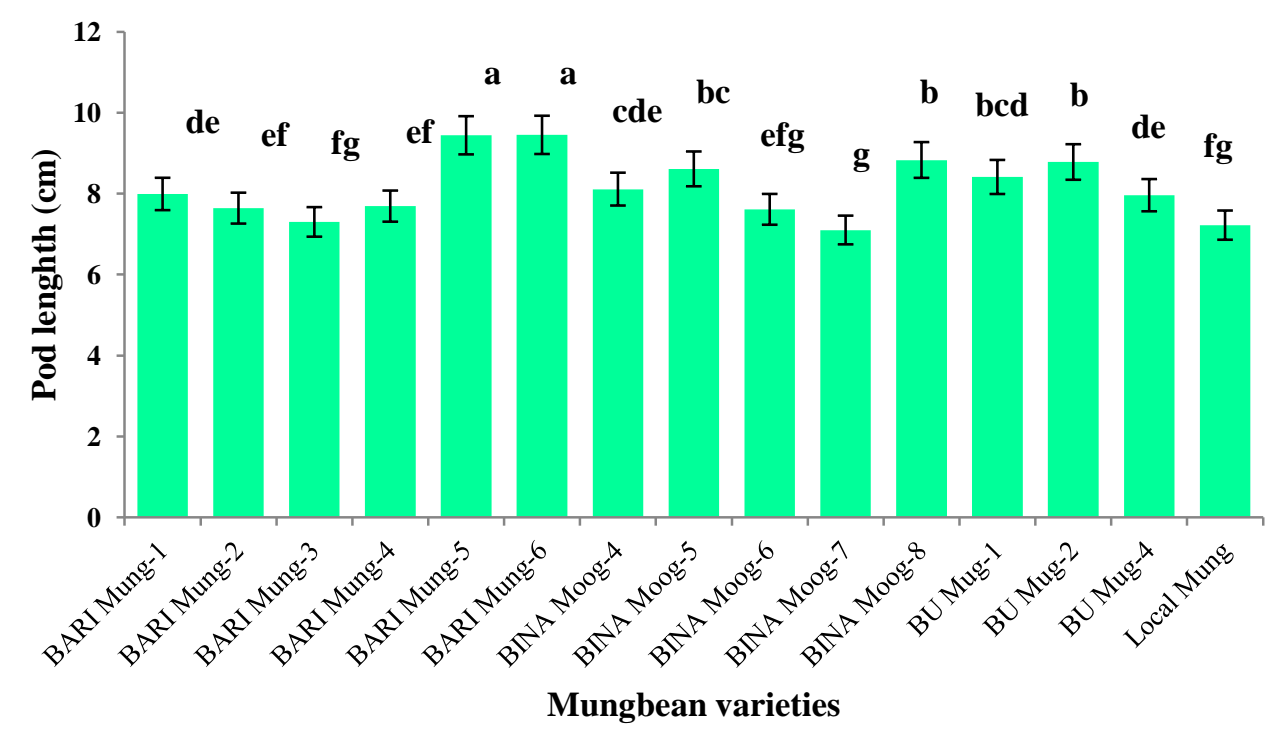

Figure 4. Effect of different varieties on the pod length of mungbean

\section{Number of seeds per pod}

Number of seeds per pod did not show significant differences among the varieties (Table 1). The maximum number of seeds per pod was observed in BARI Mung-6 (12.33) followed by BARI Mung-2 (11.66) which was similar to BINA Moog-8 (11.66) and BU Mug-1 (11.66). The minimum number of seeds per pod was obtained from Patuakhali local Mung (10.66) which was similar to BARI Mung-3, BINA Moog-6, BU Mug-2 and BU Mug-4. These results are in agreement with the findings of Aslam et al. (2004) reported non-significant differences for number of seeds per pod among different genotypes. 


\section{0 seed weight $(\mathrm{g})$}

Variety had a significant effect in 1000 seed weight and it was also observed in studied mungbean (Table 1). The 1000 seed weight under different varieties ranged from $31.00 \mathrm{~g}$ to $48.33 \mathrm{~g}$ while highest weight was recorded in BARI Mung-6 (48.33 g) followed by BARI Mung-5 (45.66 g) and BINA Moog-5 (44.00 g). In contrast, the lowest weight of 1000 seed $(\mathrm{g})$ was found in Patuakhali local Mung (31.00 g) which followed by BINA Moog-7 (32.33 g) and BARI Mung-3 (33.33 g). The variation in 1000 seed weight might be due to variation in the genetic make-up of the genotypes. Aslam et al. (2004) and Hussain et al. (2011) also reported significant differences for 1000 seed weight.

\section{Seed yield ( $\left.\mathrm{kg} \mathrm{ha}^{-1}\right)$}

In respect of seed yield, significantly the highest seed yield $\left(1065.33 \mathrm{~kg} \mathrm{ha}^{-1}\right)$ was observed in BARI Mung- 6 which statistically similar with variety BINA Moog-8 $\left(1004.33 \mathrm{~kg} \mathrm{ha}^{-1}\right)$ followed by BARI Mung-5 $\left(940.33 \mathrm{~kg} \mathrm{ha}^{-1}\right)$. The lowest seed yield $\left(490.00 \mathrm{~kg} \mathrm{ha}^{-1}\right)$ was found in Patuakhali local Mung. The BINA Moog-4 (650.00 kg $\left.\mathrm{ha}^{-1}\right)$, BU Mug-2 (603.33 $\left.\mathrm{kg} \mathrm{ha}^{-1}\right)$, BARI Mung-1 (602.67 kg ha ${ }^{-1}$ ), BINA Moog-6 $\left(599.33 \mathrm{~kg} \mathrm{ha}^{-1}\right)$ and BU Mug-1 (586.67 $\left.\mathrm{kg} \mathrm{ha}^{-1}\right)$ produces statistically similar and intermediate type of seed yield (Table 1). The seed yield was credited to BARI Mung-6 which was significantly superior over other tested varieties. This was because higher number of pods per plant, length of pod $(\mathrm{cm})$ and number of seeds per pod with highest 1000 seed weight. Patuakhali local Mung produced lowest yield might be due to lesser number of pods per plant, length of pod $(\mathrm{cm})$, number of seeds per pod and poor grain development. The finding is in close conformity with the finding of Mandal et al. (2005).

\section{CONCLUSION}

Based on the findings of the study, it was observed that fifteen (15) mungbean varieties influenced significantly in respect to yield and yield contributing factors. The results of the experiment signified that BARI Mung-6 showed comparatively better performance and should be considered for crop growing in coastal region of Bangladesh.

\section{REFERENCES}

Ali, M. (1992). Weeds are a great threat to kharif pulses. Indian Farming, 42: 29-30.

Anjum, M.S., Ahmed, Z.I. and Rauf, C.A. (2006). Effect of Rhizobium inoculation and nitrogen fertilizer on yield and yield components of moonbeam. International Journal of Agriculture and Biology, 8(2): 238-240.

Aslam, M., Hussain, M., Nadeem, M.A. and Haqqani, A.M. (2004). Comparative efficiency of different mungbean genotypes under Agro - climatic condition of Bhakhar. Pakistan Journal of Life and Social Sciences, 2(1): 51-53 
Azadi, E., Rafiee, M. and Nasrollahi, H. (2013). The effect of different nitrogen levels on seed yield and morphological characteristic of mungbean in the climate condition of Khorramabad. Annals of Biological Research, 4(2): 51-55.

BARC. (2013). Bangladesh Agricultural Research Council, Farmgate, Dhaka. Hand Book of Agricultural Technology. Pp.61.

BARI. (2011). Krishi Projukti Hatboi (Handbook on Agro-technology), $5^{\text {th }}$ edition Bangladesh Agricultural Research Institute, Gazipur-1701, Bangladesh. Pp. 164-165.

Choudhury, D.A., Hamid, A., Hasem, A. and Miah, G.U. (2000). Mungbean seed germination under soil moisture regimes. Bangladesh Journal of Agrilcultural Research, 25(2): 375-377.

Dikshit, H.K., Sharma, T.R., Singh, B.B. and Kumari, J. (2009). Molecular and morphological characterization of fixed lines from diverse cross in Munbean (Vigna radiata (L.) Wikzek). Genetics, 88: 3.

Farghali, M.A. and Hussein, H.A. (1995). Potential of genotypic and seasonal effects on yield of mung bean (Vigna radiata L. Wilczek). Assuit Journal of Agricultural Sciences, 26(2): 13-21.

Hussain, F., Malik, A.U., Haji, M.A. and Malgani, A.L. (2011). Growth and yield response of two cultivars of mungbean (Vigna radiata L.) to different potassium levels. The Journal of Animal \& Plant Sciences, 21(3): 622-625.

Iftekhar, S. and Islam, M.R. (2004). Managing mangroves in Bangladesh: A strategy analysis. Journal of Coastal Conservation, 10(1): 139-146.

Krishi Diary. (2016). Agricultural Information Services (AIS), Ministry of Agriculture, Khamarbari, Farmgate, Dhaka- 1215. Pp.15.

Mandal, S., Biswal, K.C. and Jana, P.K. (2005). Yield economics nutrient uptake and consumptive use of water by summer greengram as influenced by irrigation and phosphorous appucation. Legume Research-An International Journal, 28(2): 131-133. Mishra, S.K. (2003). Effect of rhizobium inoculation, nitrogen and phosphorous on root nodulation, protein production and nutrient uptake in cowpea (Vigna sinensisSavi). Annals of Agricultural Research: New Series, 24(1): 139-144.

Mondal, M.M.A, Dutta, R.K. and Islam, M.A. (2004). Yield performance of some mungbeanmutants in the northern region of Bangladesh. Bangladesh Journal of Nuclear Agriculture, 19: 32-35.

Mondol, M.E.A., Rahman, H., Rashid, M.H., Hossain, M.A. and Islam, M.M. (2013). Screening of mungbean germplasm for resistance to mungbean yellow mosaic virus. International Journal of Sustainable Crop Production, 8(1): 11-15.

Parvez, M.T., Paul, S.K. and Sarkar, M.A.R. (2013). Yield and yield contributing characters of mungbean as affected by variety and level of phosphorus. Journal of Agroforestry and Environment, 7(1): 115-118.

SRDI. (2005). Land and soil resource utilization guide (renewal), $2^{\text {nd }}$ edition. Patuakhali sadarupazila. Soil Resource Development Institute (SRDI), Krishi khamarsarak, Farmgate, Dhaka- 1215, Bangladesh. 